
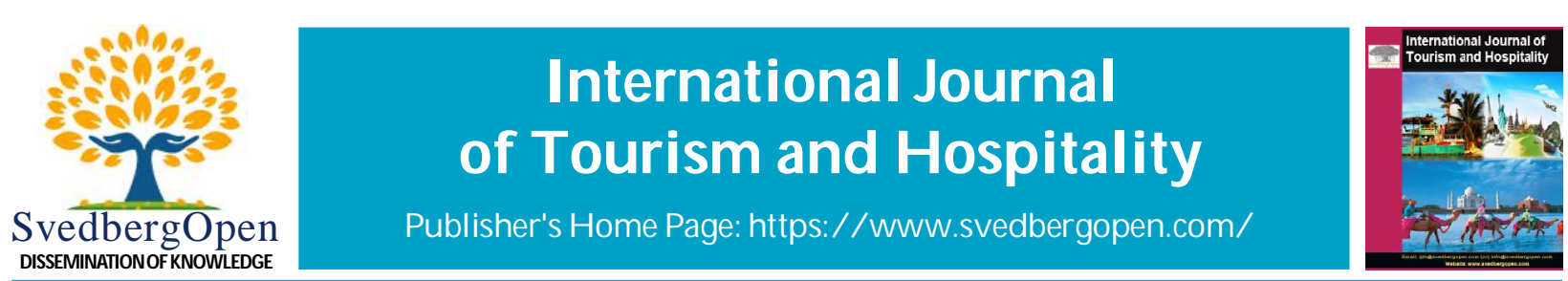

Research Paper

O pen A ccess

\title{
Tourism development and economic growth nexus in Malawi - A time-series data analysis, 1985-2015
}

\author{
Lloyd George Banda ${ }^{1 *}$ \\ 'Department of Political and Administrative Studies, University of Malawi-Chancellor College. E-mail: 1loydgeorge585@gmail.com/ \\ ma-dev-12-20@cc.ac.mw
}

\section{Article Info}

Volume 1, Issue 2, April 2021

Received : 25 December 2020

Accepted : 19 March 2021

Published : 05 April 2021

doi: $10.51483 /$ IJTH.1.2.2021.12-20

\begin{abstract}
Malawi has very few but highly attractive tourist centers and with the concerted efforts of government, tourism is becoming an essential part of the country's economy. The World Travel and Tourism Council (WTTC) in 2017 envisaged a growth of $4.9 \%$ per annum for period of 10 years for the Malawian tourism industry. In view of this, the study focuses on empirical investigation of the contribution of the fairly developing tourism sector to economic growth in Malawi. The popular time series data for the period spanning from 1985 to 2015 was analyzed with econometric STATA package. The findings reveal a no causality and negative long-run relationship between tourism development and economic growth. Meaning that neither the Tourism-Led Economic Growth (TLEG) hypothesis nor the EconomicDriven Tourism Growth (EDTG) hypothesis is confirmed for Malawi. This study provides sound policy recommendations on increasing investment in infrastructure and tourist centers for the sake of boosting tourism activities in the country though there is insufficient data leading to econometric omission such as economic freedom index and tourism related investment which were potential variables.
\end{abstract}

Keywords: Tourism development, Economic growth, Human Development Index (HDI), TOAR, STATA, World Travel and Tourism Council (WTTC)

(C) 2021 International Journal of Tourism and Hospitality. This is an open access article under the CC BY license (https://creativecommons.org/licenses/by/4.0/), which permits unrestricted use, distribution, and reproduction in any medium, provided you give appropriate credit to the original author(s) and the source, provide a link to the Creative Commons license, and indicate if changes were made.

\section{Introduction}

Economic growth is considered as the most crucial indicator of development, since it helps in reducing poverty, as it gives investors the actual background of how a particular country is faring in economy (Market Realist, 2015). Tourism over the years has proven to be a viable economic activity and a fundamental contributor to economic growth of nations by generating billions of dollars in exports and creating millions of jobs. Acknowledging these facts, many developing and developed countries today rely on tourism as an option for sustainable development of their nations. Tourism industry has now grown to be the world's largest industries and one of its fastest growing economic sectors. The recent publication of World Travel and Tourism Council ${ }^{1}$ (WTTC, 2014) showed that in 2013, travel and tourism's total contribution to the global economy rose to $\$ 7 \mathrm{tn}$, about $9.5 \%$ of global GDP, not only outpacing the wider economy but also growing faster than other significant sectors such as financial and business services, transport and manufacturing and its total contribution to employment was nearly 266 million jobs about $8.9 \%$ of world employment. The sustained

\footnotetext{
World Travel and Tourism Council (2014). Travel and Tourism Economic Impact 2014 World.
}

\footnotetext{
* Corresponding author: Lloyd George Banda, Department of Political and Administrative Studies, University of Malawi-Chancellor College.E-mail: lloydgeorge585@gmail.com/ma-dev-12-20@cc.ac.mw
} 
demand for travel and tourism, together with its ability to generate high levels of employment continues to prove the importance and value of the sector as a tool for economic development and job creation. ${ }^{2}$

Tourism today has become one of the engines of growth for Malawian economy with the total contribution of Travel \& Tourism to GDP at MWK170,886.0 mn (7.3\% of GDP) in 2014, and is envisaged to rise by $4.6 \%$ pa to MWK272,670.0 $\mathrm{mn}(5.6 \%$ of GDP) in 2025. In the same year 2014, the total contribution of travel and tourism to employment, including jobs indirectly supported by the industry, was $6.3 \%$ of total employment (233,000 jobs). This is expected to fall by $1.5 \%$ in 2015 to 229,500 jobs and rise by $0.9 \%$ pa to 252,000 jobs in 2025 ( $4.9 \%$ of total). ${ }^{3}$

Tourists come to Malawi to experience the country's treasure of flora and fauna and its immensely rich culture. Malawi has more than nine national parks and game reserves. These include the most incredibly diverse fish park in Lake Malawi- among other scenic forms of nature and wildlife. The country is also endowed with one of the most varied landscapes in Africa- with its highest peak at Mulanje mountain; $10000 \mathrm{ft}$ (3000 m) and its lowest points just above sea level. Malawi's sociable and hospitable people are also one of its greatest assets, (Malawi travel and Marketing Consortium, 2010).

Tourists that visit Malawi are also accorded with an enlightening cultural experience of the country's various traditional dances and languages. For instance, wearing facemasks is a common spectacle in Malawian traditional dances and ceremonies - most of which are usually tribe-specific. The best-known traditional dances include Gule Wamkulu, performed by the Chewa; Park Town of the Tonga, Ingoma of the Ngoni, among others, (Malawi Marketing Consortium, 2010). There is also much to see of the country's history; from the Stone Age rock paintings near Dedza to the prehistory remains of Karonga district and also other well documented artefacts in museums around the country.

While tourism development has been on the increase, Malawi's GDP has been erratic and stagnant frequently characterized by serious fluctuations and devaluations (IMF, 2015). This therefore makes it difficult to blotch the tourism-growth nexus in Malawi. This study therefore seeks to analyze the impact of tourism development on Malawi's economic growth from 1985 to 2015 and ascertain if there is any relationship between tourism and Malawi economic growth. In order to achieve the main objectives of the research, the study analyzed the specific objectives; (i) The effect of tourism on GDP; and (ii) The effects of GDP on tourism.

\section{Literature review}

Several studies that were reviewed provided a mixture of empirical literature review on impact of tourism development on economic growth globally. However, the existing empirical literature does not provide a recent clear comparative analysis on tourism and economic growth in Malawi and their conflicting results from other developing countries has generated a serious situation which has led to doubt of whether tourism development is another key element of economic growth in Malawi.

\subsection{Empirical findings}

Studies in other countries seeking to determine the link between tourism and economic growth, have established four empirical symmetries that can be translated into the following four main hypotheses: (a) Tourism-Led Economic Growth (TLEG) hypothesis (b) Economic-Driven Tourism Growth (EDTG) hypothesis, (c) Bidirectional Causality (BC) hypothesis and (d) No Causality (NC) hypothesis. ${ }^{4}$

Magombo (2011), studied tourism trend in Malawi focusing on how tourism has developed since independence but there was no quantitative evidence and no link to economic growth in this study. Another study by M' madi (2006) just focused on the determinants of international tourism in Malawi but it did not look at the impact of tourism on economic growth neither did it look at the bicausality relationship between tourism and economic growth in Malawi.

Many other empirical studies have also been conducted in other countries relating to the same topic of bilateral relationship between tourism development and economic growth across borders. Balcilar et al. (2014) conducted a study in South Africa to find the relationship between tourism and economic growth. The study used time series data from 1960 to 2012. They used the Vector Error Correction Model (VECM) and Time-Varying VECM (TV-VECM). Using

\footnotetext{
Yusuff M.A and Akinde M.A. (2015). Tourism development and economic growth nexus: Nigerian's experience, in the European Journal of Hospitality and Tourism Research, Vol. 3, No. 4, pp. 1-10, November.

World Travel and Tourism Council (2014). Travel and Tourism Economic Impact 2014 Malawi.

4 Nikolaus A, Mina D., George F. (2014). How strong is the linkage between tourism and economic growth in Europe?, (London: University College London, 2014)
} 
E-views statistical package, time series properties were carried out. However, the results revealed no causality between tourism (TR) and economic growth (GDP) for VECM and TV-VECM.

Another study conducted in Africa was done in Tunisia. The researcher Belloumi (2010) carried out his research using the country's time series data from 1970 to 2007. He used the Engle and Granger (1987) Error Correction Model (ECM), Johansen and Juselius (1990) cointegration procedure and Granger causality tests. He observed a uni-causality relationship that of TLEG. That is, increase in tourism receipts leads to an increase in economic growth. Unlike the study explained above, this study used tourism receipts as the main variable instead of international arrivals and STATA 8.2 was used.

In Aruba, one of the lesser Antilles islands in the southern Caribbean Sea attracted research interest from Ridderstaat et al. (2014). These researchers used annual data mobilized from the year 1972 to 2011. This study also used Engle and Granger (1987) ECM, Johansen and Juselius (1990) cointegration procedure and Granger causality tests and the results conformed to an EDTG hypothesis. That is to say, a uni-causality relationship was observed in which economic growth was found to be the cause to increasing numbers of tourism arrivals.

Khalil et al. (2017) conducted a research in Pakistan to find out the tourism and economic growth nexus. They used annual data for tourist receipts from 1960 to 2005. They used Engle and Granger (1987) ECM and Granger causality tests. A bicausality relationship was observed. That is, it was found out that, while tourism Granger-cause economic growth, also economic growth Granger-causes tourism.

Oh (2005) using E-views statistical package conducted a study in South Korea. The study used the country's annual data from 1975 to 2001. The study employed the Engle and Granger (1987) ECM and the Granger causality tests. Of the four main hypotheses of tourism development it was the economic growth-driven tourism hypothesis which was observed from the E-View results. That is to say, economic growth leads to increase in international tourism arrivals.

Though not exhaustive, the final empirics as per encountered by the researcher on this topic is that of Kreishan (2011). This study was conducted in Jordan using the country's annual data from 1975 to 2001 where he wanted to see the tourism and economic growth nexus. Using Statistics and data 7 (STATA 7) in which he employed Johansen and Juselius (1990) cointegration procedure and the Granger causality tests. This study also conformed to the TLEG hypothesis. Meaning that a uni-causality relationship was observed and he concluded that increase in international tourism arrivals leads to increase in economic growth.

\section{Data and methodology}

\subsection{Introduction}

This chapter presents the method used in the analysis. It includes data collection issues, modeling techniques and the estimation procedure used to achieve the objectives of the study. It also includes the necessary tests used in the study.

\subsection{Model specification and Estimation}

The study used time series data. The sample used in the study covers a time period from 1985 to 2015 . The data is obtained from the World Bank Malawi data bank and the tourism decades report from the National Statistical office.

The variables in the model used in the analysis of the relationship between tourism and economic growth are adopted from the model used by Mulkat and Mukail (2015) in a very similar study in Nigeria. The following variables were used in their study; real domestic product (GDP), Number of international Tourist Arrivals (TOAR), and Official Exchange Rate (OER). In other similar study, Makochekanwa used tourist export receipts ${ }^{5}$ as an independent variable of interest on the variables which in this case it is not available. However, from Makochekana we will adopt expected years of schooling as an add-on explanatory variable to the model herein. The following OLS model is therefore used in this study.

$$
\ln Y t=\beta_{1}+\beta_{2} \ln R E A L E X R_{t}+\beta_{3} \operatorname{lnINTERTOAR}+\beta_{3} \ln E X P S C H_{t}+\mu_{t}
$$

where;

$\begin{array}{lll}Y_{t} & : & \text { the GDP per capita } \\ \text { REALEXR }_{t} & : & \text { the real effective exchange rate used as a measure of external competitiveness } \\ \text { INTERTOAR }_{t} & : & \text { the number of international tourist arrivals } \\ \text { EXPSCH }_{t} & : & \text { Expected years of schooling } \\ \mu & : & \text { the error term }\end{array}$

${ }^{5}$ Makochekanwa, A. (n.d.). An analysis of tourism contribution to economic growth in SADC countries. Retrieved from www.ajol.info index.php/boje/article/download/94197/83596 


\subsection{Description and measurement of variables}

\subsubsection{GDP per capita}

GDP is used as a proxy for measuring economic growth. This is the dependent variable. It is taken in its natural logarithm form.

International tourist arrivals: This is the independent variable of interest and has been used as measure of tourism in the model. It is expected that when the number of tourism arrival increases, there will also be an increase in the receipts from the tourism industry. for instance, Samani et al. (2011) stressed that tourists usually demand main goods and services such as accommodation, food, transportation and entertainment services in the host country. ${ }^{6}$ Tourism is also a source of foreign currency hence; it is expected to contribute positively to economic growth. According to Galant $e t$ al. (2007), forex is the major determinant of a country's economic health and hence the well-being of all the people residing in it. ${ }^{7}$ Therefore, its coefficient is expected to be positive. The variable is used in natural logarithm form. This implies that a positive sign is expected.

Expected years of schooling: It refers to the average years spent in formal education and are calculated as the arithmetic mean of the years of schooling required to attain a given education level ${ }^{8}$. This variable is used in the model to capture human investment as it is a factor of Human Development Index (HDI). Investing in human resource is expected to have impact on economic growth in future. Our apriori expectation in this case is that human investment will have a long run positive impact on economic growth. This is so because when the individuals are educated, they will improve on the skills they use in production process. This will therefore lead to an improvement in the productivity of workers which will in turn lead to economic growth since the productivity of workers will increase. The sign of $\beta_{4}$ is therefore expected to be positive. This variable is captured in a natural log form.

Real exchange rate: Increase in exchange rate in a country shows increase in exports and this stimulates economic growth. A positive relationship is therefore expected between real effective exchange rate and economic growth. Its coefficient is therefore expected to have a positive sign. In summary the following Table 1 presents the variables and the expected signs of their coefficients.

Table 1: Variables, their expected signs and data sources

\begin{tabular}{|l|c|l|}
\hline Variables & Expected signs & Data source \\
\hline GDP per capita & + & GDP annual reports (National Statistics Office) \\
\hline International tourist arrivals & + & Tourism decades report (NSO) \\
\hline Expected years of schooling & + & World bank data bank \\
\hline Real exchange rate & + & World bank data bank \\
\hline
\end{tabular}

\subsection{Time series properties}

\subsubsection{Unit root test}

The unit root test is used to test for stationarity in the time series. Under this the Augmented Dickey-Fuller test is employed when testing for stationarity. The following equation is tested:

$\Delta y=\beta_{0}+\beta_{1} y t-1+\beta_{2} t+\Sigma A \Delta y t-1+Z t$

The following hypotheses are tested

$$
H_{0}: \beta_{1}=0 \quad H_{1}: \beta_{1}<0
$$

If we reject the null hypothesis it means that $Y_{t}$ is stationary. If that is the case, there is no need for differencing to make it stationery, i.e., it is integrated of order zero I ( 0 ). The null hypothesis is rejected when the ADF statistic is lower than the critical value since the test is left tailed. If we fail to reject the null hypothesis, it means that the time series is not integrated of order zero which implies that the time series variable is non-stationery. If the data happens to be nonstationary, there is a need for differencing to make the time series stationery.

\footnotetext{
${ }^{6}$ Samin, A.J, Sadeji, S. and Saraya, S. (2011). Tourism and economic growth in developing countries: P-value approach. Middle-East Journal of Scientific Research 10(1), 28-32.

${ }^{7}$ Galant, Mark. and Drian D. (2007). Currency Trading for Dummies. Hoboken, NJ: John Wiley and Sons.

${ }^{8}$ OECD Development Report: Education at a glance 2005 and 2006.
} 


\subsubsection{Cointegration test}

Testing for cointegration of variables of interest using the Johansen method will be applied when all the time series variables used are found to have the same order of integration. If we find out that the variables are integrated of the same order, it's when we can go ahead and apply the Johansen method of cointegration. In case where the variables are not integrated of the same order, differencing needs to be applied to make sure that the order of integration is the same before applying the Johansen method of cointegration test. For example, if some variables are integrated of order one and others are integrated of order two, those variables which are integrated of order two need to be differenced first to make them integrated of order one. If other variables are integrated of order one while others are integrated of order zero, those variables which are integrated of order zero need to be ignored when applying the Johansen Maximum likelihood method. However, if it happens that the dependent variable is integrated of order zero while some other variables are integrated of order one, we cannot ignore it and it is therefore impossible to apply cointegration analysis using the Johansen method.

In such a situation, those variables which are integrated of order one need to be differenced and there after run the OLS regression. The Johansen test is used to find out whether a long-term relationship exists among the variables. The null hypothesis in this case is that there is no cointegration among the variables. The null hypothesis is rejected when the trace statistic exceeds the critical value.

\subsubsection{Granger causality test}

After doing the cointegration analysis, the next step is to find out whether there is a causal relationship between the variables. The purpose of the Granger causality test is to investigate whether bicausality between International tourism arrivals (TOAR) and GDP(Y) exists in Malawi. The first null hypothesis is that domestic tourism arrivals does not Granger-cause GDP(Y). The second null hypothesis is that GDP(Y) does not Granger-cause international tourism arrivals (TOAR). The basis for the idea of Granger causality test is the following equation.

$$
Y_{i}=\alpha+\Sigma \beta Y_{t-1}+\Sigma \delta X_{t-1}+\mu_{t}
$$

The main idea here is that, if there is Granger causality in the direction of $Y$ from $X$, it means that the value of $Y$ at present depends on the value of $X$ at a previous time period. Rejecting the null hypothesis implies that there is Granger causality. The null hypothesis is rejected when $\alpha>p$-value and we fail to reject when $p$-value $>\alpha$.

\subsection{Diagnosis test}

There are a number of tests which are conducted. The tests for autocorrelation, model specification, and multicollinearity are conducted. According to Gujarati (1995) It is necessary to conduct such tests for us to check whether the modeling technique used in the study have adequately dealt with the common problems associated with using OLS models in time series analysis and also see how valid are the results obtained. ${ }^{9}$

\subsubsection{Autocorrelation}

Autocorrelation is the correlation in the error terms. In classical linear regression it is assumed that there is no correlation in the error terms. Since some of the assumptions of classical linear regression may not hold and also taking into consideration the fact that autocorrelation is a likely problem in time series data, it is necessary to conduct a test for autocorrelation. According to Gujarati (2004), in the presence of autocorrelation, the OLS estimators obtained are not efficient. The Breuch-Godfrey test is used to test for autocorrelation. In the presence of autocorrelation, the Newey-west method is used to get the estimators. Using the Newey-west, we are able to get the standard errors and estimators which are corrected for autocorrelation (Gujarati, 2004).

\subsubsection{Model specification}

The following are the consequences of model misspecification: the OLS estimators are biased and inconsistent; there is incorrect estimation of the disturbance variance; the results got from the hypothesis testing are misleading. The Ramsey reset test is used to check whether the model is correctly specified or not. If we find out that there is model misspecification other variables which are suggested to be important but they are excluded in the model will be added and then try to change the functional form of the model until we find out that the model is correctly specified and then rerun the correct model.

\subsubsection{Multicorrelation}

Multicollinearity is a situation where there is a linear relationship in one or more of the explanatory variables. The assumption of no multicollinearity means that no explanatory variables can be expressed in terms of another explanatory

${ }^{9}$ Domodor, N. G. (1995). Basic Econometrics. (4 $4^{\text {th }}$ ed), (McGraw-Hill: New York) pp 506-508. 
variable. In the presence of perfect multicollinearity, the coefficients cannot be determined and there are infinite standard errors. When multicollinearity is not perfect, the OLS estimators are still BLUE which implies that it is not a serious problem. However, multicollinearity becomes a serious problem when the zero-order correlation coefficient between the explanatory variables exceeds 0.8 (Gujarati, 2004). The variance inflation factor is used to test for multicollinearity in this study. There is high collinearity when the variance inflation factor is greater than 10 . In the presence of multicollinearity, the regression will be run on the differenced form of the equation. This reduces the severity of multicollinearity since even if the variables are highly collinear, their differences may not be highly collinear (Gujarati, 2004).

\section{Econometric estimation and interpretations}

\subsection{Long-run regression estimation with Newey-west standard errors}

Regression with Newey-west standard errors

Number of obs $=36$

Maximum lag: 1

$$
\begin{aligned}
& F(3,32)=7.29 \\
& \text { Prob }>F=0.0007
\end{aligned}
$$

Table 2: Long-run regression results

\begin{tabular}{|l|c|c|c|c|c|c|}
\hline \multicolumn{7}{|l|}{ Newey West } \\
\hline In_GDP_PER A & Coef. & Std. Err. & $t$ & $P>|t|$ & \multicolumn{2}{|c|}{ [95\% Conf. Interval] } \\
\hline $\ln \_$EXR & 0.0276337 & 0.1596202 & 0.17 & 0.864 & -0.297502 & 0.3527695 \\
\hline $\ln \_$TOAR & -0.0760777 & 0.033874 & -2.25 & 0.032 & -0.1450769 & -0.0070786 \\
\hline $\ln$ SCH & 0.4828097 & 0.5687263 & 0.85 & 0.402 & -0.6756479 & 1.641267 \\
\hline _cons & 0.0596251 & 6.659288 & 0.01 & 0.993 & -13.5049 & 13.62415 \\
\hline Source: Author's secondary data analysis using STATA & & & & \\
\hline
\end{tabular}

Table 2 shows the long run regression results with the Newey-west standard errors. The results above show that expected years of schooling and real exchange rate in Malawi have a significant impact on economic growth.

For the variables of interest, the results of the Newey-west regression show that there is a significant negative relationship between tourism arrivals and economic growth at 5\% significance level. Specifically, a $1 \%$ increase in domestic tourism arrivals will lead to approximately a $0.076 \%$ decrease in GDP. That is, in the long run tourism arrivals is insignificant at 5\% level of significance in influencing economic growth. This befouls the apriori expectation that increase in tourism arrivals will lead to increase in GDP.

While the variable of interest does not conform to the a priori expectation, exchange rate and the expected years of schooling do. For example, the results show that there is a significant positive relationship between both exchange rate and expected years of schooling to economic growth at 5\% significance level. A $1 \%$ increase in exchange rate and expected years of schooling leads to $0.027 \%$ and $0.059 \%$ increase in GDP respectively.

\subsection{Short-run regression estimation with Newey-west standard errors}

Regression with Newey-west standard errors

Number of obs $=35$

Maximum lag: 1

$F(3,31)=5.80$

Prob $>F=0.0029$

Table 3: Short-run regression results

\begin{tabular}{|l|c|c|c|c|c|c|}
\hline \multicolumn{1}{|l|}{ Newey West } \\
\hline dln_GDP_PER A & Coef. & Std. Err. & T & $P>|t|$ & \multicolumn{2}{|c|}{ [95\% Conf. Interval] } \\
\hline dln_EXR & -0.1071414 & 0.064119 & -1.67 & 0.105 & -0.237913 & 0.0236302 \\
\hline dln_TOAR & -0.2232686 & 0.1273285 & -1.75 & 0.089 & -0.4829569 & 0.0364196 \\
\hline
\end{tabular}




\begin{tabular}{|l|c|c|c|c|c|c|}
\hline \multicolumn{7}{|l|}{ Table 3 (Cont.) } \\
\hline dIn_GDP_PER $\sim$ A & Coef. & Std. Err. & T & P>|t| & \multicolumn{2}{|c|}{ [95\% Conf. Interval] } \\
\hline dln_SCH & -1.078007 & 0.303122 & -3.56 & 0.001 & -1.696229 & -0.459786 \\
\hline _cons & 0.1409094 & 0.0542706 & 2.60 & 0.014 & 0.0302237 & 0.2515951 \\
\hline Source: Author's secondary data analysis using STATA \\
\hline
\end{tabular}

Table 3 shows the short-run regression results which shows a significant negative relationship between all the variables and economic growth. For example, a 1\% increase in exchange rate, tourism arrivals and expected years of schooling leads to a $0.10 \%, 0.22 \%$ and $1.07 \%$ decrease in GDP. In the short run, exchange rate is significant at $10 \%$ significance level while secondary school enrolment is significant at $5 \%$ significance level.

\subsection{Granger causality Wald test}

The objectives of this study focused on finding out the nexus between tourism and economic growth. The results in the Table 4 indicate that economic growth does not Granger-cause tourism since the Prob $>\mathrm{Chi}^{2}$ corresponding to the null hypothesis that economic growth does not Granger-cause tourism is greater than alpha hence we fail to reject it, which implies that economic growth does not Granger-cause tourism.

\begin{tabular}{|l|c|c|c|}
\hline Table 4: Granger causality Wald test results \\
\hline Null Hypothesis & Chi2 & Df & Prob>Chi2 \\
\hline TOAR “does not cause economic growth" & 1.3371 & 2 & 0.512 \\
\hline Economic growth does not cause TOAR & 1.9638 & 2 & 0.375 \\
\hline Source: Author's secondary data analysis using STATA \\
\hline
\end{tabular}

The null hypothesis that tourism does not Granger-cause economic growth is rejected at 5\% significance level since the Prob $>\mathrm{Chi}^{2}$ is less than the alpha which implies that growth in tourism Granger-causes economic growth.

\subsection{Stationarity test results}

The Augmented Dickey-Fuller test was used to test for the stationarity of the time series variables used in this study. All the variables were found to be non-stationary in their level form. All the variables were found to be stationary in their differenced form. This means that the variables used in the analysis are integrated of order one.

\subsection{Cointegration test results}

Table 5 of the results of the Johansen test for cointegration shows that at both rank zero up to four, the trace statistic is greater than the critical value. This means that the null hypothesis of no cointegration is rejected which implies that there is a long-term relationship between tourism arrivals and economic growth.

Table 5: Johansen cointegration test results

\begin{tabular}{|l|c|c|}
\hline Maximum rank & Trace statistic & 5\% critical value \\
\hline 0 & 143.4276 & 47.21 \\
\hline 1 & 87.5790 & 29.68 \\
\hline 2 & 42.5349 & 15.41 \\
\hline 3 & 14.6838 & 3.76 \\
\hline \multicolumn{2}{|c|}{ Source: Author's secondary data analysis using STATA } \\
\hline
\end{tabular}




\subsection{Diagnostic test results}

In the long run equation, the Breuch Godfrey test was conducted to test for serial correlation. It was found out that in the long run there was a problem of serial correlation and this problem was dealt with by running a regression with Neweywest standard errors.

The variance inflation factor was used to test for multicollinearity and it was found out that in the long run model there is a problem of multicollinearity but in the short run model there is no problem of multicollinearity.

The Ramsey reset test was used to find out if there are omitted variables and the results indicated that the model has no omitted variables. For the short run equation, the Breuch Godfrey test indicated that there is no serial correlation. The Ramsey reset test indicated that the model has no omitted variables, and multicollinearity is not a problem in the short run.

\section{Conclusion and recommendations}

\subsection{Summary of findings}

This study examined the dynamic relationship between tourism development and economic growth in Malawi for the period between 1985 to 2015 . The OLS estimation techniques were applied to the econometrics model of this study. The Granger causality test was executed to test for bicausality relationship between tourism and economic growth. Adopting the concepts and methods of the cointegration and Granger causality test, the study investigated the short-term dynamic relations and long-run equilibrium conditions. Regression results indicated that, in the long run tourism has a negative impact on economic growth. This means tourism was significant in influencing economic growth since the result showed that $1 \%$ increase in tourist arrivals decreases GDP by $0.076 \%$. In the short run, the impact of tourism on economic growth was found to be insignificant. Similar to the findings of Balcilar et al. (2014) using data for South Africa, a No causality and positive significant long-run equilibrium relationship exist in Malawi.

\subsection{Recommendations}

The study confirmed on exchange rate affecting economic growth though with a lesser percentage and also accepted education development (HDI) as an accelerator of Malawi economic growth with the highest percentage.

The study findings were found in agreement with theoretical assumptions that assumes that exchange rate and education development affect GDP positively though the study did not agree on the main variable, tourist arrivals affecting GDP positively and therefore it can be concluded in this study that the assumption did not hold. For example, the negative sign for the tourist arrivals variable was against the theoretical expectation of the study, meaning that most of these theories lack applicability in developing countries such as Malawi. Therefore, there is a need for countries to always be cautious when it comes to applying such theories and always take in what is related to the country's situation. A long-term solution to this would be for developing countries such as Malawi to invest heavily in improving the capacity of its researchers in order for these economists to generate and harness indigenous knowledge with which they can come up with growth models that are responsive to the socioeconomic and political conditions and characteristics of Malawi.

\subsection{Limitations of the study}

The major limitation of this study is that some variables which were supposed to be included in the model were not included due to unavailability of data in Malawi. For example, the economic freedom index, and tourism related investments were not included because data on those variables was not available. This explains why this research does not make recommendations on the provision of adequate security for both domestic and foreign tourists, tax incentives to tourism industries and good transport system.

\section{References}

Balcilar, M., R. van Eyden, and R. Inglesi Lotz (2014). Time varying linkages between Tourism Reciepts and Economic growth in south Africa. Applied economics. 46(36), 4381-4398.

Belloumi, M. (2010). The relationship between tourism reciepts, real effective exchange rate and economic growth in Tnisia. International Journal of Tourism Research. 12, 550-560.

Engle, R. and Granger, C. (1987). Cointegration and Error Correction: Representation, Estimation and Testing. Econometrica. 55, 251-276. http://dx.doi.org/10.2307/1913236. 
Galant, Mark, and Drian D. (2007). Currency Trading for Dummies. Hoboken, NJ: John Wiley and Sons.

Gujarati D.N. (1995). Basic Econometrics. 4th edition, McGraw-Hill: New York, 506-508.

Gujarat, D.N. (2004). Basic Econometrics. 4th edition. McGraw-Hill, New York.

Johansen, S. and Juselius, K. (1990). Maximum likelihood estimation and inference on cointegration with applications to demand for money. Oxford Bulletin of Economics and Statistics. 52, 169-210.

Khalil, S., M. Kakar, and W.Waliallah. (2007). Role of tourism in economic growth: Emperical evidence from Pakistan economy. Pakistan Development Review. 46(4), 985-995.

Kreishan, F. (2011). Time series evidence for tourism-Led growth hypothesis. A case of Jordan. International Management Review. 7(1), 89-93.

Magombo, A. (2011). The Development of Tourism and the Accommodation Sector in Malawi since Independence.

Market Realist (2015). Gauging Chinese Tourism's Important Role in Ctrips' Growh [online]. Accessed from: https:// marketrealist.com/2015/12/gauging-chinese-tourisms-important-role-ctrips-growth/ [19 September 2020].

Mulkat, Y.A. and Akinde, Mukail, A. (2015). Tourism development and economic growth nexus: Malawis Experience. European Journal of Hospitality and Tourism Research. 3(4), 1-10.

Oh., C. (2005). The contribution of tourism development to economic growth in the Korean economy. Tourism Management, 26, 39-44.

OECD Development Report: Education at a glance 2005 and 2006.

Phiri A, "Tourism and Economic growth in South Africa: Evidence Linear and Nonlinear Cointegration Frameworks" (South Africa: North West University).

Ridderstaat, J., Croos, R. and Nijikamp, P. (2014). 'Tourism and long-run economic growth in Aruba. International Journal of Tourism Research. 16(5), 472-487.

Samin A.J, Sadeji, S. and Saraya, S. (2011). Tourism and economic growth in developing countries: p-value approach. Middle-East Journal of Scientific Research. 10(1), 28-32.

World Travel and Tourism Council (WTTC), (2014). Travel and Tourism Economic Impact 2014, Malawi.

Cite this article as: Lloyd George Banda (2021). Tourism development and economic growth nexus in Malawi - A time-series data analysis, 1985-2015. International Journal of Tourism and Hospitality. 1(2), 12-20. doi: 10.51483/ IJTH.1.2.2021.12-20. 